\title{
UREDITEV VOLILNIH ENOT V DRŽAVNOZBORSKEM VOLILNEM SISTEMU
}

\section{dr. Boštjan Rogelj}

Oddelek za geografijo, Filozofska fakulteta Univerze v Ljubljani

Aškerčeva 2, SI-I000 Ljubljana

e-mail: bostjan.rogelj@ff.uni-lj.si

Izvirni znanstveni članek

COBISS 1.01

\section{Izvleček}

V prvem delu članka so predstavljeni nekateri vidiki oblikovanja volilnih enot v volilnih sistemih, zasnovanih na proporcionalni volilni formuli. Drugi del članka je namenjen analizi volilnih enot v volilnem sistemu za volitve poslancev v Državni zbor Republike Slovenije. Poudarjeni so dejavniki, ki so sprožili nastanek specifične trinivojske ureditve z osmimi volilnimi enotami, nacionalno ravnjo delitve mandatov ter 88 volilnimi okraji. Sledi analiza ureditve volilnih enot in volilnih okrajev $\mathrm{z}$ vidika izpolnjevanja načel enake volilne pravice, homogenosti in kompaktnosti.

Ključne besede: volilna geografija, volitve, volilni sistemi, volilne enote, Slovenija, Državni zbor Republike Slovenije

\section{ARRANGEMENT OF CONSTITUENCIES IN ELECTORAL SYSTEM USED FOR THE ELECTIONS TO THE NATIONAL ASSEMBLY OF SLOVENIA}

\begin{abstract}
The first part of this article presents some aspects of creating constituencies in electoral systems based on proportional electoral formula. The second part is an analysis of the constituencies in the electoral system that selects representatives for the National Assembly. Emphasized are the factors that engendered Slovenia's specific three-level organization of constituencies. The last part is an analysis of the organization of constituencies and electoral districts in light of fulfilling the principles of voter equality, homogeneity and compactness.
\end{abstract}

Key words: electoral geography, elections, electoral systems, electoral districts, Slovenia, National Assembly of the Republic of Slovenia 


\section{I.UVOD}

Predstavniška demokracija je ena temeljnih značilnosti sodobnih demokratičnih držav. Ljudstvo na volitvah podeli mandat predstavnikom, ki v njegovem imenu izvršujejo oblast (Grad, 2004, str. 17). Komu bo mandat podeljen, pa ni odvisno le od volje ljudstva oziroma volivcev, temveč tudi od volilnega sistema. Volilni sistem določa, kako se glasovi volivcev prevedejo v poslanske mandate znotraj volilnega procesa. Sestavljen je iz različnih med seboj tesno povezanih in soodvisnih elementov, med katerimi je z vidika geografije najpomembnejša ureditev volilnih enot (Rae, 1971; Lijphart, 1994; Farrell, 2001; Norris, 2004; Rogelj, 2011).

Volilne enote lahko najpreprosteje opredelimo kot geografska območja, na katera je razdeljena država v volilne namene (Reynolds, Reilly, 1997, str. 146), oziroma kot geografsko območje, znotraj katerega se zbirajo oddani volilni glasovi in so razdeljeni sedeži v predstavniškem telesu (Cox, 1997; cv: Krašovec, 2007, str. 53). V volilni sistem so navadno vključene zaradi želje po enakomernejši prostorski porazdelitvi mandatov, tesnejši povezanosti volivcev in poslancev ter lažji organizaciji in izvedbi volitev.

$\mathrm{V}$ volilnih sistemih, zasnovanih na proporcionalni volilni formuli, delitev ozemlja na volilne enote načeloma ni potrebna oziroma je celo nezaželena. Vsaka delitev ozemlja na volilne enote namreč zmanjšuje stopnjo proporcionalnosti delitve mandatov, zato se v omenjenih sistemih uporablja le takrat, ko mora volilni sistem poleg proporcionalnosti izpolniti še kakšno drugo vrednoto. Navadno se uporablja za zagotavljanje geografske reprezentativnosti volilnega sistema ali za okrepitev povezanosti med poslanci in volivci (Rogelj, 2011).

Oblikovalci volilnih sistemov, zasnovanih na proporcionalni formuli, imajo pri urejanju volilnih enot relativno proste roke. Posledično je za omenjene sisteme značilna velika raznolikost v ureditvi ključnih lastnosti volilnih enot (velike razlike v številu volilnih enot, njihovi velikosti oziroma številu mandatov, ki se volijo v posamezni enoti, prostorskem obsegu in številu ravni, uporabljenih pri delitvi mandatov). Edina omejitev, ki jo morajo upoštevati pri načrtovanju, je povezana z zagotavljanjem pravičnosti in enakosti. Enako kot ureditev drugih elementov volilnega sistema mora tudi ureditev volilnih enot vsem volivcem ponuditi enake pogoje za sodelovanje na volitvah, hkrati pa mora dati glasovom volivcev enako težo.

Pri oblikovanju volilnih enot se zagotavljanje pravičnosti in enakosti kaže v stopnji spoštovanja načel enake volilne pravice, geografske homogenosti in geografske kompaktnosti volilnih enot. V skladu s prvim načelom morajo biti volilne enote oblikovane tako, da ima glas vsakega volivca enako vrednost (Grad, 2004), oziroma da enako število prebivalcev/volivcev voli en mandat. Načelo homogenosti se nanaša na zahtevo, da meje volilnih enot ne delijo družbenih skupin, ki živijo v prostorsko zaokroženih območjih (ACE Project, 2011). Načelo kompaktnosti pa se nanaša na zahtevo, da so volilne enote oblikovane tako, da obsegajo zaključene oziroma kompaktne prostorske enote.

V članku želimo preučiti, v kolikšni meri so bila pri oblikovanju volilnih enot v volilnem sistemu za volitve poslancev v Državni zbor Republike Slovenije upoštevana zgoraj našteta načela, ki so ključna z vidika zagotavljanja pravičnosti in enakosti volilnega sistema. Hkrati 
želimo preveriti, v kolikšni meri so korenite spremembe v prostorski razporeditvi prebivalstva ter reforma lokalne samouprave vplivale na spoštovanje omenjenih načel, saj ureditev volilnih enot vse od leta 1992 ni doživela bistvenih sprememb.

Raziskava je razdeljena na dva dela. V teoretično-metodološkem delu so najprej predstavljeni razlogi za uporabo volilnih enot in različni pristopi pri njihovem oblikovanju v volilnih sistemih, zasnovanih na proporcionalni formuli. V nadaljevanju so prikazana nekatera teoretična izhodišča pri preučevanju načela enake volilne pravice, načela homogenosti in načela kompaktnosti. Obravnavani so glavni problemi, povezani z njihovim preučevanjem. Hkrati so predstavljene nekatere kvantitativne in kvalitativne metode, s katerimi lahko opredelimo stopnjo izpolnjevanja omenjenih načel. V empiričnem delu so najprej predstavljeni dejavniki, ki so vplivali na oblikovanje zelo specifične večslojne ureditve volilnih enot v državnozborskem volilnem sistemu. Po tej ureditvi je Slovenija razdeljena na enajst volilnih enot, v katerih poteka primarna medstrankarska delitev mandatov, in na 88 volilnih okrajev, v katerih poteka znotrajstrankarska delitev mandatov. V nadaljevanju je prikazano, v kolikšni meri sta ureditvi volilnih enot in volilnih okrajev skladni z načeli enake volilne pravice, homogenosti in kompaktnosti. $\mathrm{V}$ ta namen je bila izdelana kvantitativna in kvalitativna analiza stopnje spoštovanja omenjenih načel od leta 1992 do leta 2011. Opozoriti namreč velja, da ureditev volilnih enot in volilnih okrajev vse od oblikovanja leta $1992 \mathrm{ni}$ doživela pomembnejših sprememb, čeprav je v zadnjih dvajsetih letih prišlo v Sloveniji do pomembnih sprememb v prostorski razporeditvi prebivalstva in smo bili v tem obdobju priča korenitim spremembam ureditve lokalne samouprave.

\section{VOLILNE ENOTE V VOLILNIH SISTEMIH, ZASNOVANIH NA PROPORCIONALNI VOLILNI FORMULI}

Volilni sistemi, zasnovani na proporcionalni volilni formuli, so se uveljavili v začetku 20. st. kot odgovor na korenite spremembe v prostorski delitvi mandatov in organiziranosti volitev po uveljavitvi splošne in enake volilne pravice (Harrop, Miller, 1987, str. 47). Njihova glavna prednost je sorazmerna delitev mandatov. Ta je močno odvisna od različnih formalnih in neformalnih omejitev, ki določajo, katere stranke lahko sodelujejo pri delitvi mandatov. Raziskave so pokazale, da je velikost volilnih enot (s terminom velikost volilne enote označujemo število mandatov, ki se volijo v volilni enoti) eden najpomembnejših dejavnikov, ki vplivajo na stopnjo proporcionalnosti delitve mandatov. Majhne volilne enote namreč učinkujejo kot visok dejanski volilni prag in tako onemogočajo manjšim strankam, da sodelujejo pri delitvi mandatov (Lijphart, 1994). Z naraščanjem velikosti volilnih enot se dejanski volilni prag znižuje, s tem pa se povečuje proporcionalnost delitve mandatov (preglednica 1). Najvišjo stopnjo proporcionalnosti dosežemo, če je celotno ozemlje, na katerem potekajo volitve, ena volilna enota.

Čeprav delitev ozemlja na volilne enote znižuje stopnjo proporcionalnosti, jo danes najdemo v večini volilnih sistemov, zasnovanih na proporcionalni volilni formuli. Razloge za to lahko iščemo v dejstvu, da morajo omenjeni volilni sistemi poleg proporcionalne delitve mandatov izpolniti tudi nekatere druge cilje oziroma vrednote. 
Preglednica 1: Ocena višine dejanskega volilnega praga na podlagi velikosti volilne enote Table 1: Estimated effective threshold for different district magnitude

\begin{tabular}{|l|c|c|c|c|c|c|c|}
\hline $\begin{array}{l}\text { Velikost } \\
\text { volilne } \\
\text { enote }\end{array}$ & $\begin{array}{c}\text { Dejanski } \\
\text { volilni prag }\end{array}$ & $\begin{array}{c}\text { Velikost } \\
\text { volilne } \\
\text { enote }\end{array}$ & $\begin{array}{c}\text { Dejanski } \\
\text { volilni prag }\end{array}$ & $\begin{array}{c}\text { Velikost } \\
\text { volilne } \\
\text { enote }\end{array}$ & $\begin{array}{c}\text { Dejanski } \\
\text { volilni prag }\end{array}$ & $\begin{array}{c}\text { Velikost } \\
\text { volilne } \\
\text { enote }\end{array}$ & $\begin{array}{c}\text { Dejanski } \\
\text { volilni prag }\end{array}$ \\
\hline 1 & 37,50 & 6 & 10,71 & 11 & 6,25 & 40 & 1,83 \\
\hline 2 & 25,00 & 7 & 9,38 & 15 & 4,69 & 45 & 1,63 \\
\hline 3 & 18,75 & 8 & 8,33 & 20 & 3,57 & 50 & 1,47 \\
\hline 4 & 15,00 & 9 & 7,50 & 25 & 2,88 & 75 & 0,99 \\
\hline 5 & 12,50 & 10 & 6,82 & 30 & 2,42 & 100 & 0,74 \\
\hline
\end{tabular}

Vir/Source: lastni izračuni na podlagi formule iz Gallagher, Mitchell (2008)

Delitev ozemlja na volilne enote je nujna, kadar mora volilni sistem zagotoviti določeno stopnjo geografske reprezentativnosti. Z delitvijo ozemlja na volilne enote se posameznim območjem zagotovi zastopanost v predstavniškem telesu ne glede na volilne rezultate. Če ozemlje ni razdeljeno na volilne enote oziroma če so te zelo velike, obstaja nevarnost, da bo večina izvoljenih poslancev prišla iz pomembnih političnih, gospodarskih in prebivalstvenih središč v državi, medtem ko redko poseljena, politično in gospodarsko manj pomembna območja ne bodo imela svojih predstavnikov (Farrell, 2001). Vendar velja opozoriti, da delitev ozemlja na volilne enote sama po sebi še ne zagotavlja geografske reprezentativnosti volilnega sistema. Ta je namreč močno odvisna od geografije volilnih enot oziroma od tega, v kolikšni meri se pri njihovem oblikovanju upoštevajo načela enake volilne pravice, homogenosti in kompaktnosti. Predvsem je pomembno, da je razmerje med številom mandatov, voljenih v določeni volilni enoti, sorazmerno s številom prebivalcev/volivcev (Rogelj, 2011).

Delitev ozemlja na volilne enote je nujna tudi, kadar mora volilni sistem zagotoviti tesnejšo povezanost med poslanci in volivci. Od nje je močno odvisna stopnja personifikacije volilnega sistema, t.j. vpliv volivca na izbiro kandidata. V manjših enotah ima volivec boljši pregled nad kandidati, kar mu omogoča, da poleg strank voli tudi posamezne kandidate (v obliki preferenčnega glasovanja, panaširanja ...). Zadnje je laže izvedljivo tudi z organizacijskega in tehničnega vidika. Nasprotno je v zelo velikih volilnih enotah glasovanje o kandidatih bolj nepregledno ter tehnično in organizacijsko bolj zapleteno. Zato je tudi redkeje omogočeno, navadno pa manj vpliva na volilne rezultate (Krašovec, 2007).

Delitev ozemlja na volilne enote se lahko uporablja tudi za zniževanje stopnje proporcionalnosti volilnega sistema. Visoka stopnja proporcionalnosti pogosto povzroča pretirano razdrobljenost predstavniškega telesa, s tem pa je oteženo sklepanje vladajočih koalicij in sprejemanje odločitev. Z oblikovanjem volilnih enot se ustvari neformalni volilni prag (preglednica 1), ki manjšim strankam preprečuje pridobitev mandata, s tem pa se zmanjšuje razdrobljenost predstavniškega telesa.

Pri oblikovanju volilnih enot v volilnih sistemih, zasnovanih na proporcionalni volilni formuli, zasledimo dva pristopa (ACE Project, 2011). V prvo skupino spadajo volilni sis- 
temi, pri katerih se najprej določi prostorski obseg volilnih enot, velikost volilne enote pa se določi na podlagi števila prebivalcev oziroma drugih meril. Prostorski obseg volilnih enot je navadno prilagojen mejam pomembnejših upravno-teritorialnih enot (pri volitvah $\mathrm{v}$ nacionalne parlamente se meje volilnih enot navadno skladajo z mejami pokrajin, regij, zveznih dežel, provinc itd.; ACE Project, 2011).

Takšen način oblikovanja se uporablja, kadar je geografska reprezentativnost najpomembnejši cilj oziroma vrednota volilnega sistema. Njegova glavna prednost je v tem, da vsaki upravno-teritorialni enoti zagotavlja natančno določeno število predstavnikov v predstavniškem telesu. Zaradi uskladitve meja volilnih enot z uveljavljenimi upravno-teritorialnimi enotami je zanje značilna visoka stopnja homogenosti. Poleg tega je celoten proces oblikovanja volilnih enot preprost in pregleden. Ker je prostorski obseg določen že vnaprej, je treba določiti le sistem, po katerem se mandati razdelijo po posameznih volilnih enotah. Večina sistemov delitve mandatov temelji na eni od metod največjega ostanka (najbolj znan je enostavni oziroma Harejev količnik), redkeje temeljijo na metodah največjega povprečja (najbolj znan je d'Hondtov sistem), pri čemer se kot osnova za izračune uporablja število prebivalcev v volilnih enotah, le redko so uporabljena druga merila, kot so število volivcev, površina volilne enote, udeležba na zadnjih volitvah itd.

Med pomanjkljivostmi velja poudariti velike razlike v velikosti posameznih volilnih enot ter z njo povezano kršenje načela enake volilne pravice. Nekatere upravno-teritorialne enote imajo premalo prebivalcev, da bi bile upravičene do svojega predstavnika v predstavniškem telesu. Zato je njihovo zastopstvo v predstavniškem telesu mogoče le ob zavestnem kršenju načela enake volilne pravice, ki vodi k nadpovprečni zastopanosti majhnih in podpovprečni zastopanosti velikih volilnih enot. Velike razlike v velikosti volilnih enot hkrati ustvarjajo pomembne razlike $\mathrm{v}$ naravi strankarskega tekmovanja med velikimi in majhnimi volilnimi enotami. V velikih volilnih enotah je dejanski volilni prag relativno nizek, zato je strankarsko tekmovanje bolj naklonjeno manjšim strankam, ki laže pridobijo poslanski mandat. Nasprotno velja za manjše volilne enote, v katerih je dejanski volilni prag relativno visok, kar odvrača manjše stranke od sodelovanja na volitvah oziroma jim onemogoča pridobitev mandata (Monroe, Rose, 2002).

V drugo skupino spadajo sistemi, v katerih se najprej določi velikost volilnih enot, temu pa sledi določitev njihovega prostorskega obsega (ACE Project, 2011). Čeprav je ta pristop tipičen za volilne sisteme, zasnovane na večinski formuli, ga izjemoma najdemo tudi v sistemih, ki temeljijo na proporcionalni formuli. Pri zadnjih je takšen pristop navadno povezan z zakonskim določilom, po katerem se v vseh volilnih enotah voli enako število mandatov, in z odsotnostjo ustrezne upravne delitve ozemlja, na katerem potekajo volitve.

Prav oblikovanje velikostno enakih volilnih enot, v katerih se voli večje število mandatov, je glavna prednost opisanega načina oblikovanja volilnih enot. Ker prostorski obseg in z njim povezano število prebivalcev v volilni enoti nista vnaprej določena, lahko oblikovalci volilnega sistema sami odločajo o številu in velikosti volilnih enot. Po navadi oblikujejo manjše število enako velikih volilnih enot, v katerih se voli večje število mandatov. Večje volilne enote zagotavljajo višjo stopnjo proporcionalnosti delitve mandatov, saj je dejanski volilni prag, ki ga ustvarjajo volilne enote, nižji kot pri manjših enotah. Poleg tega so zaradi enake velikosti vseh volilnih enot razmere, v katerih se odvija medstrankarsko tekmovanje, 
v vseh volilnih enotah enake. Posledično so tudi možnosti za pridobitev mandata povsod enake.

Med pomanjkljivostmi drugega pristopa velja poudariti problem nehomogenosti in nekompaktnosti volilnih enot. Razdeliti ozemlje na enako velike volilne enote, ki so skladne $\mathrm{z}$ načelom enake volilne pravice, pogosto zahteva delitev družbeno, ekonomsko in kulturno homogenih območij oziroma združitev nepovezanih, nehomogenih območij. Tudi pri tem pristopu se poskušajo meje volilnih enot uskladiti z mejami uveljavljenih upravno-teritorialnih enot, vendar se zaradi zgoraj navedenih omejitev pri tem namesto večjih oziroma višjih enot upravno-teritorialne delitve uporabljajo manjše oziroma nižje enote, kot so občine, naselja, četrti itd. Opisani pristop daje oblikovalcem volilnih sistemov relativno proste roke pri določitvi ključnih značilnosti volilnih enot. Poleg zagotavljanja dovolj visoke stopnje proporcionalnosti delitve mandatov je edina pomembnejša omejitev zagotavljanje pravičnosti in enakosti ureditve. Zelo pomembno je namreč, da tudi ureditev volilnih enot ne diskriminira določenih volivcev oziroma da da glasovom vseh volivcev enako težo. Uvodoma je bilo poudarjeno, da se pravičnost in enakost ureditve kaže v stopnji spoštovanja načel enake volilne pravice, geografske homogenosti in geografske kompaktnosti volilnih enot (Toplak, 2000; Morrill, 1981; Cox, Katz, 2002; Monmonier, 2001). V nadaljevanju so predstavljene nekatere metode, uporabljene za preučevanje spoštovanja omenjenih načel.

Načelo enake volilne pravice zahteva, da ima glas vsakega volivca enako vrednost (Grad, 2004). To pomeni, da mora enako število prebivalcev/volivcev voliti en mandat oziroma enega predstavnika. Če se v vseh volilnih enotah voli enako število mandatov, morajo imeti vse volilne enote približno enako število prebivalcev. Če se v volilnih enotah voli različno število mandatov, pa mora biti v vseh volilnih enotah zagotovljeno enako razmerje med številom mandatov in številom prebivalcev/volivcev.

Stopnjo spoštovanja načela enake volilne pravice lahko relativno preprosto kvantitativno opredelimo. Najpreprostejše merilo je razmerje proporcionalnosti (RP; angl. proportionality ratio), ki pomeni razmerje med deležem izvoljenih predstavnikov iz regije $\left(\mathrm{s}_{\mathrm{i}}\right)$ in deležem prebivalstva v regiji $\left(\mathrm{p}_{\mathrm{i}}\right)$. Če doseže vrednost 1 , govorimo o popolni proporcionalnosti. Rezultati nad ena kažejo na nadpovprečno zastopanost določene regije (angl. over-representation), rezultati pod ena pa na njeno podpovprečno zastopanost (angl. under-representation; Latner, McGann, 2004, str. 5).

$$
\text { razmerje proporcionalnosti } \mathrm{RP}=\frac{\mathrm{s}_{\mathrm{i}}}{\mathrm{p}_{\mathrm{i}}}
$$

Razmerje proporcionalnosti nam pove, ali je določeno območje/volilna enota nadpovprečno ali podpovprečno zastopana v predstavniškem telesu, ne pove pa nam, v kolikšni meri je spoštovano načelo enake volilne pravice celotne ureditve volilnih enot. Le-to lahko izračunamo s pomočjo različnih indeksov neproporcionalnosti. Neskladje med deležem mandatov in deležem prebivalstva posamezne volilne enote je v matematičnem pogledu enakovredno neskladju med deležem glasov in deležem mandatov posamezne stranke (Monroe, 1994, str. 132-133), zato lahko za računanje obeh uporabimo enake postopke oziroma metode. Med različnimi indeksi neproporcionalnosti se za merjenje stopnje spoštovanja 
načela enake volilne pravice danes najpogosteje uporablja indeks najmanjših kvadratov, ki ga izračunamo na podlagi deleža prebivalstva $v$ regiji $\left(\mathrm{p}_{\mathrm{i}}\right)$ in deleža izvoljenih predstavnikov iz regije $\left(\mathrm{s}_{\mathrm{i}}\right)$. Pri popolnem upoštevanju omenjenega načela je vrednost indeksa enaka nič, višje vrednosti pa kažejo na večja odstopanja od načela enake volilne pravice.

$$
\text { indeks najmanjših kvadratov } D_{i s}=\sqrt{\frac{1}{2} \sum_{i=1}^{N}\left(p_{i}-s_{i}\right)^{2}}
$$

Drugo pomembno načelo je načelo homogenosti. Skladno z njim naj bi bile volilne enote oblikovane tako, da posameznim socialnim, ekonomskim oziroma kulturnim skupinam, ki živijo v prostorsko zaokroženih območjih, omogočajo izvolitev predstavnikov, ki bodo zastopali njihove interese (ACE Project, 2011). Pri oblikovanju volilnih enot bi se morali izogibati nepotrebnemu deljenju homogenih skupin na več volilnih enot, s čimer se zmanjšuje njihova politična moč. Zaželeno je, da se meje volilnih enot skladajo z mejami prostorskih enot, ki so funkcijsko povezane oziroma katerih prebivalci imajo skupno identiteto. V proporcionalnih sistemih, za katere so značilne večje volilne enote, to navadno pomeni, da se meje volilnih enot uskladijo z mejami višjih upravno-teritorialnih enot, kot so regije, pokrajine, province, zvezne dežele in podobno. Uskladitev volilnih enot z obstoječimi upravnoteritorialnimi enotami je pomembna tudi zato, ker poenostavlja in olajša organizacijo volitev (tehnično izvedbo vseh postopkov), to pa zmanjšuje finančne stroške njihove izvedbe. Vsi volilni postopki se namreč lahko izvedejo v okviru obstoječih institucij in organov. Za te enote je navadno značilna relativno močna regionalna pripadnost prebivalcev, zato postanejo izvoljeni poslanci predstavniki svojih regij.

Z načelom homogenosti je tesno povezano načelo kompaktnosti. Skladno z njim morajo biti volilne enote oblikovane tako, da obsegajo zaključene oziroma kompaktne prostorske enote. Nezaželena je prostorska razčlenjenost ali celo razdeljenost volilnih enot. Razmejitev mora upoštevati različne naravno- in družbenogeografske dejavnike oziroma se opreti na obstoječo upravno-teritorialno delitev države.

Spoštovanje načel homogenosti in kompaktnosti je zelo težko kvantitativno izmeriti, zato ni presenetljivo, da kljub nekaterim poizkusom kvantifikacije (Taylor, Johnston, 1979; Gudgin, Taylor, 1979) danes v strokovni literaturi ne najdemo kvantitativnih meril, na podlagi katerih bi določali, kako homogena ali kompaktna je posamezna volilna enota oziroma celotna ureditev volilnih enot (Taylor, Johnston, 1979). Posledično je ugotavljanje spoštovanja omenjenih načel pogosto omejeno na različne kvalitativne analize, v katerih se členitve ozemlja na volilne enote primerjajo z drugimi uveljavljenimi oblikami členitve teritorija, na katerem potekajo volitve. V praksi se ureditev volilnih enot največkrat primerja z različnimi upravno-teritorialnimi členitvami ozemlja oziroma geografskimi regionalizacijami, saj te navadno povezujejo družbeno, ekonomsko, funkcijsko oziroma kulturno zaokrožena območja. 


\section{VOLILNE ENOTE IN VOLILNI OKRAJI V DRŽAVNOZBORSKEM VOLILNEM SISTEMU}

Temelji obstoječega volilnega sistema za volitve poslancev v Državni zbor Republike Slovenije so bili postavljeni v Zakonu o volitvah v Državni zbor iz leta 1992 (Zakon je bil pozneje večkrat dopolnjen in preoblikovan, a so njegove osnovne poteze ostale nespremenjene.). Njegovi ustvarjalci so želeli hkrati uveljaviti dve nasprotujoči si vrednoti. Ob čim bolj proporcionalni medstrankarski delitvi mandatov so želeli volivcem omogočiti, da s svojim glasovanjem vplivajo na znotrajstrankarsko delitev mandatov oziroma kadrovsko sestavo Državnega zbora Republike Slovenije. Poleg tega so želeli, da bi volilni sistem omogočil parlamentarno zastopanost različnim območjem v državi. Naštete zahteve so pripeljale do oblikovanja unikatnega volilnega sistema $\mathrm{z}$ relativno zapletenim sistemom delitve mandatov ter večslojno ureditvijo volilnih enot. Za državnozborski volilni sistem so značilne tri ravni volilnih enot, in sicer 88 volilnih okrajev, osem volilnih enot in nacionalna volilna enota.

Primarna medstrankarska delitev mandatov poteka v osmih enajstmandatnih volilnih enotah na podlagi Droopovega količnika. Nerazdeljeni mandati se uporabijo pri sekundarni delitvi na nacionalni ravni, pri čemer se tako dobljeni mandati dodelijo listam po volilnih enotah. Takšen način delitve zagotavlja visoko stopnjo proporcionalnosti celotnega volilnega sistema, hkrati pa ohrani njegovo geografsko reprezentativnost, saj je v vsaki volilni enoti izvoljenih točno 11 poslancev. Znotrajstrankarska delitev mandatov, z njo pa tudi personifikacija volitev, poteka na ravni volilnih okrajev. Mandat stranke pripade tistemu strankinemu kandidatu v volilni enoti, ki je v svojem volilnem okraju dobil največji delež glasov.

Zaradi želje po zagotovitvi čim večje proporcionalnosti volilnega sistema in ker ni primerne upravno-teritorialne členitve države, je bil pri oblikovanju volilnih enot uporabljen drugi od dveh prej opisanih pristopov. Skladno s tem pristopom je bila najprej določena velikost, pozneje pa prostorski obseg volilnih enot. S členitvijo države na enako velike volilne enote, pri oblikovanju katerih je bilo strogo spoštovano načelo enake volilne pravice, sta bili zagotovljeni visoka stopnja proporcionalnosti delitve mandatov in geografska reprezentativnost volilnega sistema.

Želja po oblikovanju enako velikih volilnih enot je ob dejstvu, da se v volilnih enotah voli 88 mandatov, močno skrčila število razpoložljivih možnosti. Prvotni predlog je predvideval oblikovanje enajstih volilnih enot, v katerih bi se volilo osem mandatov (Grad, 2011), pozneje je bil na željo politikov sprejet predlog osmih volilnih enot, v katerih se voli po enajst mandatov. Glede na število prebivalcev v državi in zaradi spoštovanja načela enake volilne pravice je bilo določeno, da je v posamezni volilni enoti od 230.773 do 255.065 prebivalcev (Rogelj, 2011). Na geografijo oziroma prostorski obseg volilnih enot je odločilno vplivala upravno-teritorialna členitev države na občine. Oblikovalci volilnega sistema so se namreč odločili, da bodo meje volilnih enot uskladili z občinskimi mejami. Omenjena odločitev je skupaj z zahtevo po doslednem spoštovanju načela enake volilne pravice pripeljala do oblikovanja osmih relativno nehomogenih in nekompaktnih volilnih enot. 
Slika 1: Meje volilnih enot in volilnih okrajev leta 1992

Figure 1: The borders of constituencies (volilna enota) and electoral districts (volilni okraj) in 1992

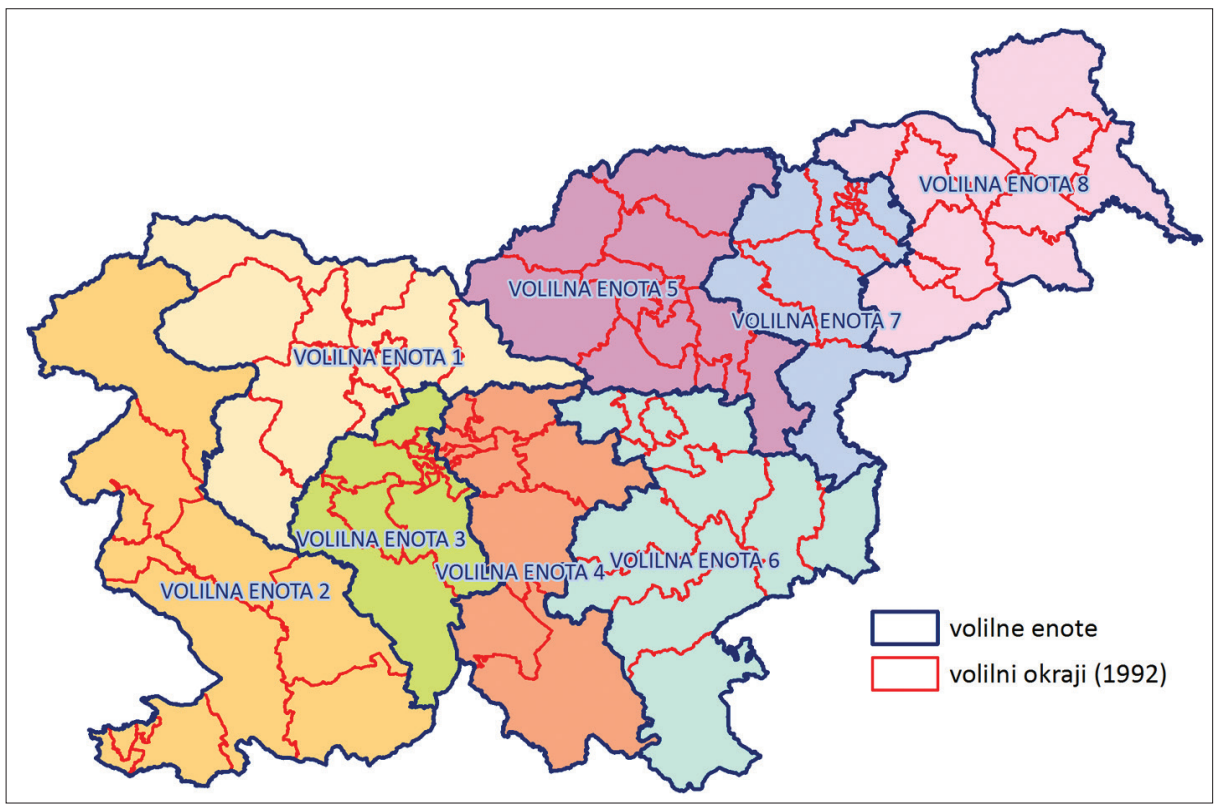

Vir/Source: Rogelj, 2011

Že prej smo omenili, da je vseh osem volilnih enot razdeljenih na enajst volilnih okrajev. Zaradi želje po zagotovitvi čim višje stopnje personifikacije je bilo določeno, da bodo vsi volilni okraji enako veliki oziroma da bo v vsakem kandidiral le po en kandidat vsake stranke (Opozoriti velja, da v volilnih okrajih ni medstrankarske delitve mandatov. Volilni izidi v volilnih okrajih so pomembni le z vidika znotrajstrankarske delitve mandatov, zato ne moremo govoriti o enomandatnih volilnih okrajih.). Prvotno je bilo predvideno, da bodo vsi volilni okraji imeli približno enako število prebivalcev/volivcev (od 20.444 do 24.986 prebivalcev). Nazadnje je bil zaradi pritiska politikov sprejet sklep, da se pri njihovem oblikovanju upoštevajo geografska zaokroženost in skupne značilnosti ozemlja (Ustavno sodišče, 1992). V praksi je to pomenilo, da so se meje volilnih okrajev, če je bilo to mogoče, usklajevale z mejami takratnih občin.

Razloge za takšno odločitev lahko iščemo v tem, da so bile občine edine pomembne enote lokalne samouprave v državi, ki so zaradi dolgotrajnega obstoja in relativne velikosti sčasoma prevzele vlogo manjših funkcijskih oziroma nodalnih regij. Poleg tega je bila podobna rešitev uporabljena že na volitvah leta 1990. Z navezavo volilnih okrajev na občine so lokalne skupnosti dobile možnost, da v Državni zbor Republike Slovenije izvolijo 'svojega' predstavnika. Poleg tega je omenjena rešitev poenostavila tudi izvedbo volitev, saj so številna volilna opravila lahko opravile obstoječe občinske institucije. 


\section{IZPOLNJEVANJE KLJUČNIH NAČEL}

Že prej so bili predstavljeni ključni dejavniki, ki so vplivali na določitev temeljnih značilnosti volilnih enot in volilnih okrajev v državnozborskem volilnem sistemu. V nadaljevanju je predstavljeno, v kolikšni meri njihova ureditev spoštuje načela enake volilne pravice, homogenosti ter kompaktnosti in ali so spremembe v prostorski razporeditvi prebivalstva in večkratne reforme lokalne samouprave vplivale na spoštovanje zgoraj naštetih načel.

Izračuni razmerij proporcionalnosti in indeksa najmanjših kvadratov (narejeni na podlagi števila volivcev in deleža izvoljenih mandatov po posameznih volilnih enotah na volitvah leta 1992) kažejo na visoko stopnjo spoštovanja načela enake volilne pravice v času nastanka sistema (preglednici 2 in 3). Enake rezultate kažejo tudi poznejši izračuni. Nizka vrednost indeksa najmanjših kvadratov za volitve leta 2011 kaže, da so spremembe v razporeditvi prebivalstva celo pozitivno vplivale na spoštovanje načela enake volilne pravice. $\mathrm{K}$ temu je največ pripomoglo dejstvo, da prvotno 'podpovprečno zastopane' volilne enote beležijo počasnejšo rast števila volivcev kot prvotno 'nadpovprečno zastopane' volilne enote. Tako sta se prva in sedma volilna enota, ki sta leta 1992 po številu volivcev celo rahlo presegali dovoljeni prag odstopanja, v zadnjem obdobju močno približali idealni velikosti. Tudi zdaj, dvajset let po njihovem nastanku, ne moremo govoriti o nesorazmerni zastopanosti posameznih volilnih enot, saj nobena ne odstopa za več kot pet odstotkov od velikosti t.i. 'idealne oziroma povprečne volilne enote' (preglednica 2). Še najbolj se omenjeni meji približa četrta volilna enota, ki je bila podpovprečno zastopana že leta 1992, zaradi hitre rasti prebivalstva pa utegne že zelo kmalu preseči 5-odstotni prag odstopanja.

Preglednica 2: Število volivcev po volilnih enotah in razmerje proporcionalnosti v obdobju 1992-2011 Table 2: The number of voters in each constituency and the proportionality ratio in the period 1992-2011

\begin{tabular}{|c|c|c|c|c|c|c|c|c|c|}
\hline & Leto & VE 1 & VE 2 & VE 3 & VE 4 & VE 5 & VE 6 & VE 7 & VE 8 \\
\hline \multirow{6}{*}{ 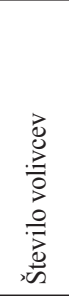 } & 1992 & 176.319 & 181.077 & 181.955 & 189.635 & 191.514 & 180.415 & 197.539 & 192.920 \\
\hline & 1996 & 183.653 & 187.115 & 188.093 & 197.657 & 198.067 & 184.981 & 202.536 & 197.116 \\
\hline & 2000 & 191.762 & 193.262 & 193.178 & 205.035 & 204.559 & 190.346 & 206.691 & 201.862 \\
\hline & 2004 & 199.066 & 199.016 & 200.003 & 213.016 & 210.190 & 196.159 & 210.218 & 206.734 \\
\hline & 2008 & 207.340 & 208.959 & 208.492 & 221.434 & 215.961 & 204.594 & 215.053 & 214.604 \\
\hline & 2011 & 209.270 & 210.890 & 213.011 & 223.685 & 216.177 & 205.698 & 215.357 & 215.604 \\
\hline \multirow{6}{*}{ 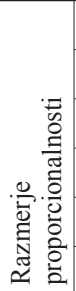 } & 1992 & 1,06 & 1,03 & 1,02 & 0,98 & 0,97 & 1,03 & 0,94 & 0,97 \\
\hline & 1996 & 1,05 & 1,03 & 1,02 & 0,97 & 0,97 & 1,04 & 0,95 & 0,98 \\
\hline & 2000 & 1,03 & 1,03 & 1,03 & 0,97 & 0,97 & 1,04 & 0,96 & 0,98 \\
\hline & 2004 & 1,03 & 1,03 & 1,02 & 0,96 & 0,97 & 1,04 & 0,97 & 0,99 \\
\hline & 2008 & 1,02 & 1,01 & 1,02 & 0,96 & 0,98 & 1,04 & 0,99 & 0,99 \\
\hline & 2011 & 1,02 & 1,01 & 1,00 & 0,96 & 0,99 & 1,04 & 0,99 & 0,99 \\
\hline
\end{tabular}

Viri/Sources: Kropivnik, 1996; SURS, 1996, 2000, 2004; Volitve v Državni zbor 2008; Predčasne volitve v Državni zbor 2011 
Preglednica 3: Vrednosti indeksa najmanjših kvadratov za ureditev volilnih enot v obdobju 1992-2008

Table 3: The values of least squares index in the period 1992-2008

\begin{tabular}{|l|r|r|r|r|r|r|}
\hline & 1992 & 1996 & 2000 & 2004 & 2008 & 2011 \\
\hline Indeks najmanjših kvadratov & 0,935 & 0,875 & 0,804 & 0,739 & 0,617 & 0,591 \\
\hline
\end{tabular}

Viri/Sources: Kropivnik, 1996; SURS, 1996, 2000, 2004; Volitve v Državni zbor 2008

Preverjanje spoštovanja načela enake volilne pravice na ravni volilnih okrajev je formalnopravno nesmiselno, saj v njih ne poteka medstrankarska delitev mandatov (Ustavno sodišče, 1992). Ima pa število prebivalcev/volivcev v volilnih okrajih pomemben vpliv na znotrajstrankarsko delitev mandatov (Rogelj, 2011), zato so v nadaljevanju predstavljene nekatere ključne značilnosti števila volivcev v volilnih okrajih.

Prej opisani postopek oblikovanja je ustvaril z vidika števila volivcev zelo heterogene volilne okraje. Leta 1992 je imelo le 33 volilnih okrajev število volivcev, ki je za manj kot deset odstotkov odstopalo od števila volivcev v idealnem volilnem okraju (njegova velikost je enaka kvocientu med številom volivcev v celotni državi in številom volilnih okrajev). Premajhnih je bilo 31, prevelikih pa 24 volilnih okrajev. Problematični so bili predvsem štirje najmanjši (Hrastnik, Ribnica, Tržič in Izola) in osem največjih okrajev (Nova Gorica I, Jesenice, Murska Sobota II, Šmarje pri Jelšah, Celje II, Celje I, Slovenska Bistrica in Murska Sobota I), ki so za več kot tretjino odstopali od idealne velikosti.

Spremembe v prostorski razporeditvi prebivalstva so močno vplivale na velikost volilnih okrajev oziroma na odstopanje njihove velikosti od velikosti idealnega volilnega okraja. Primerjava velikosti v obdobju 1992-2011 kaže na nekatere pomembne trende (sliki 2 in 3 ter preglednica 4). Najbolj opazno je občutno povečanje velikosti idealnega volilnega okraja ter večanje razlike med najmanjšim in največjim volilnim okrajem (leta 2011 je ta znašala že več kot 21.800 volivcev). Z vidika variabilnosti števila volivcev je značilno povečevanje absolutne in stagnacija relativne mere variabilnosti. Kljub relativno majhnim spremembam v relativni variabilnosti pa velja opozoriti na dva negativna trenda. Prvi je nenehno upadanje števila volilnih okrajev, ki za manj kot deset odstotkov odstopajo od velikosti idealnega volilnega okraja. Tako je bilo leta 2011 takšnih le še 24 volilnih okrajev. Drugi je nastanek skrajno velikih volilnih okrajev. Nadpovprečna rast števila volivcev v največjih volilnih okrajih je pripeljala do nastanka volilnih okrajev, ki so za več kot polovico večji od idealnega. Na drugi strani je značilna stagnacija števila premajhnih volilnih okrajev, pri čemer je zelo pomembno, da se bistveno ne povečuje število tistih, ki najbolj odstopajo od povprečja.

Zelo značilne so tudi občutne regionalne razlike v spreminjanju velikosti volilnih okrajev. Najopaznejši je relativen, ponekod pa tudi absoluten upad števila volivcev v pretežno urbanih volilnih okrajih (absoluten upad beležijo volilni okraji Maribor IV, Ljubljana Šiška I, Maribor VII, Maribor V, Celje II in Ljubljana Center). Relativni upad je značilen tudi za nekatera periferna območja, še posebno tista z resnimi gospodarskimi problemi. Med njimi velja omeniti Pomurje, Posočje ter večji del Spodnjega Posavja in Zasavja. Nasprotni trend je značilen za volilne okraje, ki obsegajo širši suburbani regiji Ljubljane in Kopra, v manjši 
meri tudi suburbana območja nekaterih drugih regionalnih središč. V teh volilnih okrajih število volivcev močno narašča.

Na podlagi povedanega ugotavljamo, da sodobni demografski trendi niso pripomogli $\mathrm{k}$ zmanjšanju velikih razlik v velikostni sestavi volilnih okrajev, zato te ostajajo ena ključnih značilnosti njihove zdajšnje ureditve.

Preglednica 4: Nekateri pomembni statistični parametri za spremenljivko število volivcev po volilnih okrajih' za leta 1992, 1996, 2000, 2004, 2008 in 2011

Table 4: Selected statistics for the variable 'number of voters in electoral district' in the period 1992-2011

\begin{tabular}{|l|r|r|r|r|r|r|}
\hline & 1992 & 1996 & 2000 & 2004 & 2008 & 2011 \\
\hline $\begin{array}{l}\text { Velikost idealnega volilnega okraja } \\
\text { (volivcev) }\end{array}$ & $16.947,4$ & $17.491,1$ & $18.030,6$ & $18.572,8$ & $19.277,7$ & $19.428,3$ \\
\hline Število 'idealnih' VO & 33 & 35 & 33 & 29 & 28 & 24 \\
\hline Standardni odklon & 3780,6 & 3843,3 & 3943,1 & 4108,7 & 4372,4 & 4497,4 \\
\hline Koeficient variacije (\%) & 22,31 & 21,97 & 21,87 & 22,12 & 22,68 & 23,15 \\
\hline $\begin{array}{l}\text { Indeks velikosti najmanjšega volilnega } \\
\text { okraja }\end{array}$ & 50,0 & 47,5 & 46,4 & 46,2 & 45,4 & 43,9 \\
\hline Indeks velikosti največjega volilnega okraja & 149,6 & 148,6 & 150,8 & 151,7 & 152,7 & 156,4 \\
\hline $\begin{array}{l}\text { Razlika med največjim in najmanjšim } \\
\text { volilnim okrajem (volivcev) }\end{array}$ & 17.070 & 17.709 & 18.853 & 19.631 & 20.707 & 21.854 \\
\hline
\end{tabular}

Viri/Sources: Kropivnik, 1996; SURS, 1996, 2000, 2004; Volitve v Državni zbor 2008; Predčasne volitve v Državni zbor 2011

Spoštovanja načel homogenosti in kompaktnosti pri oblikovanju volilnih enot in volilnih okrajev ni mogoče kvantitativno opredeliti, ga je pa mogoče oceniti s primerjavo ureditve volilnih enot in volilnih okrajev z različnimi upravno-teritorialnimi členitvami države. Medtem ko je ureditev volilnih okrajev najbolje primerjati s členitvijo države na občine, je $\mathrm{z}$ vidika volilnih enot omenjena primerjava neustrezna. Občine nam zaradi majhnosti ne dajejo ustreznih informacij o homogenosti in kompaktnosti posameznih volilnih enot. $\mathrm{V}$ ta namen bi bila ustreznejša primerjava $\mathrm{z}$ regionalno ravnjo lokalne samouprave. Le-ta $\mathrm{V}$ Sloveniji še vedno ni uveljavljena, zato so za primerjavo uporabljene nekatere predlagane regionalizacije Slovenije na pokrajine, ki so nastale v zadnjih petnajstih letih (Plut, 2004). Čeprav se omenjeni predlogi med seboj razlikujejo v številu, velikosti in prostorskem obsegu bodočih pokrajin, je vsem skupna želja po oblikovanju geografsko, ekonomsko in kulturno čim bolj homogenih pokrajin. Ravno zato jih lahko uporabimo kot merilo za ocenjevanje stopnje homogenosti obstoječih volilnih enot oziroma kot podlago za morebitno alternativno členitev države na volilne enote.

Če ureditev volilnih enot primerjamo z nekaterimi predlaganimi členitvami na pokrajine (slika 4; Plut, 2004), ugotovimo, da se meje volilnih enot v številnih primerih ne skladajo z mejami uveljavljenih pokrajin, in to ne glede na izbrano pokrajinsko členitev. Številna odstopanja in nesmiselne členitve opazimo tako pri primerjavi s členitvijo na manjše število 
Slika 2: Indeks velikosti volilnih okrajev glede na velikost idealnega volilnega okraja na podlagi števila volivcev leta 1992

Figure 2: The number of voters in electoral districts compared to the number of voters of the 'ideal' electoral district in 1992

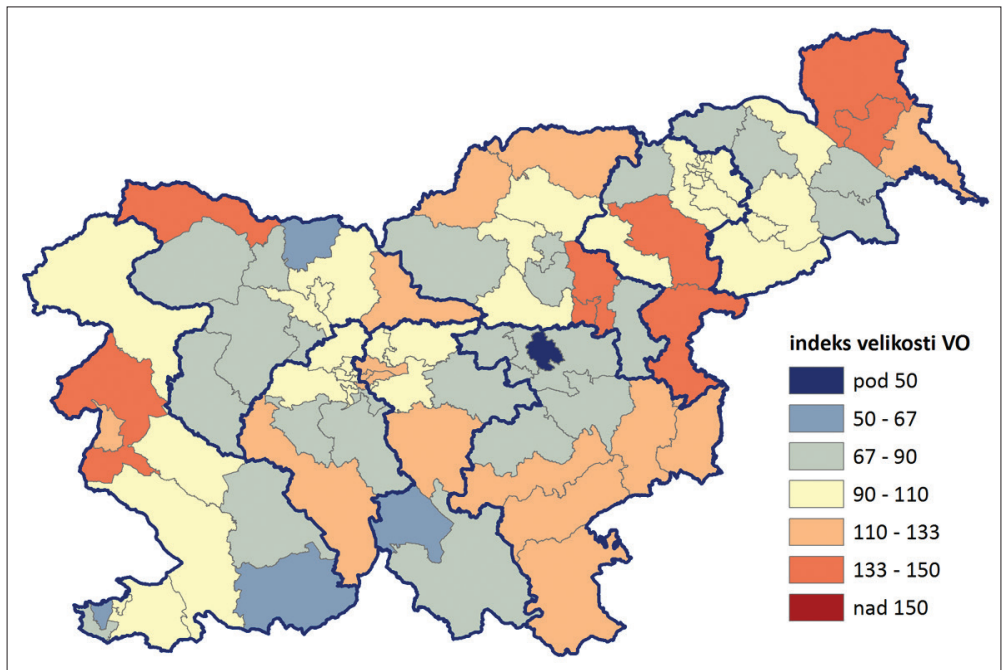

Vira/Sources: Kropivnik, 1993, 1996

Slika 3: Indeks velikosti volilnih okrajev glede na velikost idealnega volilnega okraja leta 2011 Figure 3: The number of voters in electoral districts compared to the number of voters of the 'ideal' electoral district in 2011

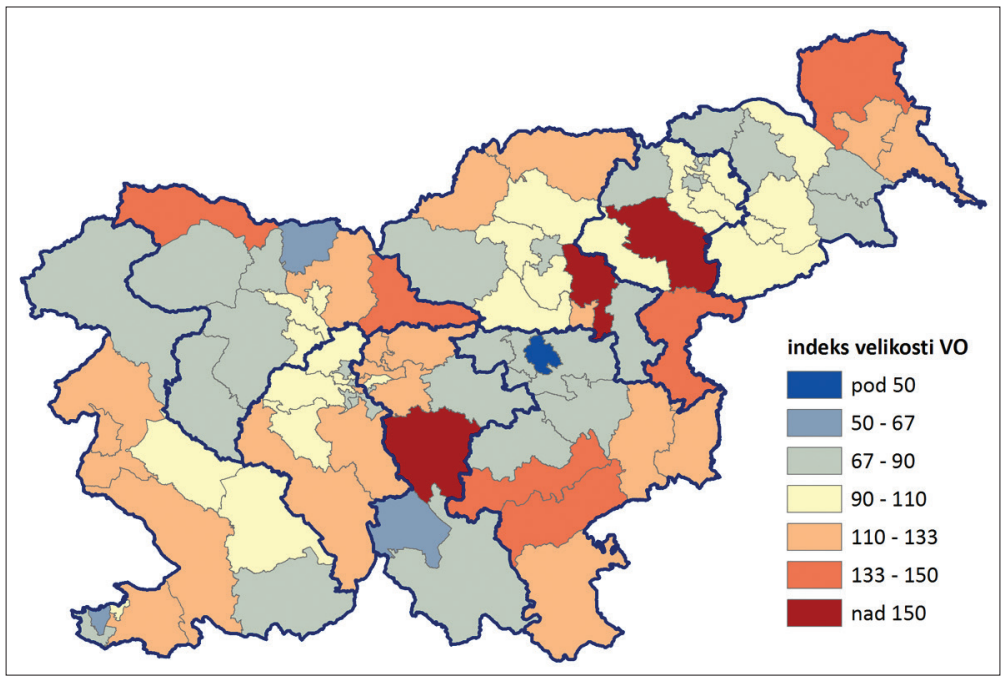

Vir/Source: Predčasne volitve v Državni zbor 2011 
večjih regij kot pri primerjavi z večjim številom manjših regij. Meje volilnih enot združujejo oziroma delijo ozemlja večine uveljavljenih regij, in to kljub zakonskemu določilu, po katerem naj bi se pri oblikovanju volilnih enot upoštevali načelo geografske zaokroženosti ter skupne kulturne in druge značilnosti ozemlja.

Najspornejša je delitev Ljubljane na dve volilni enoti. Ko so nastale sedanje volilne enote, je bilo območje zdajšnje mestne občine Ljubljana razdeljeno na pet občin. Občine Vič-Rudnik, Šiška in Center so postale del tretje volilne enote, Bežigrad in Moste-Polje pa četrte volilne enote. Oblikovanje ene same volilne enote na območju vse petih občin je bilo zaradi njihove velikosti nemogoče, nastala delitev pa je najbolj smiselno sledila takratnim občinskim mejam.

Problematična je tudi razmejitev nekaterih drugih volilnih enot. Prva volilna enota s središčem v Kranju tako poleg vseh gorenjskih občin obsega tudi občini Kamnik in Idrija. Medtem ko prvo pogojno še lahko uvrstimo med gorenjske občine (Klemenčič, 2005), pa to nikakor ne velja za Idrijo, ki regionalno in funkcionalno prej spada $v$ drugo volilno enoto. Druga volilna enota je med vsemi še najbolj homogena, saj z izjemo občine Idrija obsega celotno Primorsko regijo.

Med bolj problematičnimi sta tudi peta in sedma volilna enota s sedežem v Celju oziroma Mariboru. Prva ne vključuje občin Laško in Šmarje pri Jelšah, ki regionalno gledano spadata v peto volilno enoto. Druga volilna enota ne vključuje občine Pesnica, ki leži v neposrednem zaledju Maribora, vključuje pa relativno oddaljeno občino Šmarje pri Jelšah. Z vključitvijo zadnje ni kršeno le načelo homogenosti, ampak je grobo kršeno tudi načelo geografske kompaktnosti sedme volilne enote. V šesti volilni enoti s sedežem v Novem mestu je problematična vključitev nekdanje občine Laško in vseh treh zasavskih občin. Prva tradicionalno gravitira proti Celju, preostale tri pa proti Ljubljani, zato bi prej spadale v peto oziroma četrto volilno enoto.

Iz zapisanega je razvidno, da so volilne enote kljub zakonskemu določilu, da je treba pri oblikovanju volilnih enot in volilnih okrajev poleg načela enake volilne pravice upoštevati še geografsko zaokroženost ter skupne kulturne in druge značilnosti, zelo nehomogene, nekatere tudi nekompaktne. Za večino volilnih enot je značilno, da združujejo območja, ki $\mathrm{v}$ regionalnem pogledu ne spadajo skupaj oziroma niso medsebojno povezana, kar onemogoča povezovanje posameznih mandatov s specifično regijo.

Nasprotno velja za volilne okraje. Pri njih je bilo načelo enake volilne pravice podrejeno zahtevi po oblikovanju geografsko zaokroženih območij s skupnimi kulturnimi in drugimi značilnostmi. Z uskladitvijo meja volilnih okrajev z občinskimi so nastali relativno homogeni in kompaktni volilni okraji. V preteklosti sta izstopali le dve večji anomaliji. Prva je bila posledica združitve logaške in cerkniške občine v prvi volilni okraj tretje volilne enote. Z njo je nastal podolgovat, nekompakten volilni okraj, ki je segal od Rovt v logaški občini pa vse do Babnega Polja. Podoben položaj je nastal z delitvijo občine Novo mesto na dva volilna okraja, od katerih je eden zavzemal severni del občine, drugi pa južnega, vsakemu pa je pripadel del naselja Novo mesto. Medtem ko prva anomalija obstaja še danes, so drugo leta 2004 s preoblikovanjem obeh novomeških okrajev odpravili. 
Slika 4: Primerjava členitve na volilne enote z nekaterimi predlaganimi pokrajinskimi členitvami Figure 4: Comparison of constituencies' arrangement with different propositions for the regionalization of Slovenia

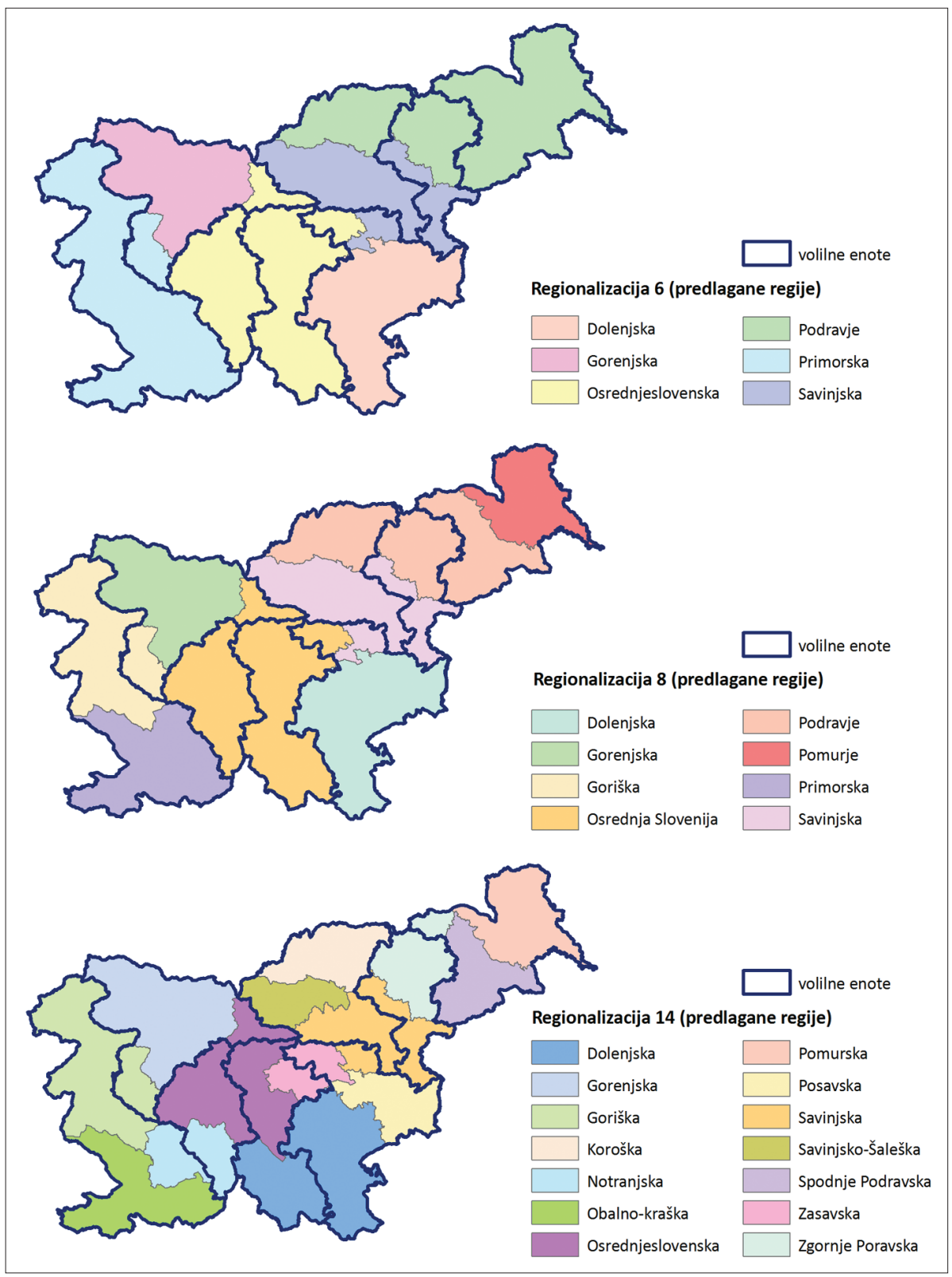

Vira/Sources: Plut, 2004; SURS, 2001 
Številne reforme lokalne samouprave, ki so bile izvedene v Sloveniji od leta 1992 naprej, so korenito spremenile upravno-teritorialno delitev države na občine. Zato ni presenečenje, da meje obstoječih volilnih okrajev v številnih primerih odstopajo od zdajšnjih občinskih meja. Odstopanja lahko v grobem razdelimo v štiri skupine.

V prvo spadajo občine, ki morajo biti zaradi velikosti razdeljene na dva ali več volilnih okrajev. V tej skupini so mestne občine Ljubljana, Maribor, Kranj, Koper, Celje in Novo mesto, pogojno tudi mestni občini Velenje in Nova Gorica ter občina Domžale. Vse naštete občine so v preteklosti obsegale veliko večje območje, zato so praviloma razdeljene na več volilnih okrajev, kot bi bilo primerno glede na zdajšnje število prebivalcev.

V drugo skupino spadajo občine, ki so imele leta 1992 preveč prebivalcev za en sam volilni okraj in so bile zato razdeljene na dva, z reformo lokalne samouprave pa se je njihova velikost močno zmanjšala. Omenjene občine so tako razdeljene na več volilnih okrajev, čeprav bi glede na število prebivalcev lahko tvorile en sam volilni okraj. V tej skupini sta mestni občini Murska Sobota in Ptuj ter občina Žalec (Murska Sobota ima zdaj 19.346, Ptuj 23.629, Žalec pa 21.483 prebivalcev; SURS, 2011).

Tretjo skupino sestavljajo nove občine, nastale na ozemlju nekdanjih velikih občin, ki so razdeljene na več volilnih okrajev. Vanjo spadajo občine Brezovica, Škofljica in Dol pri Ljubljani v okolici Ljubljane, Hoče-Slivnica in Pesnica v okolici Maribora ter občini RenčeVogrsko in Moravske Toplice. V podobnem položaju se je znašla tudi občina Železniki, vendar je bila njena delitev s spremembo Zakona o določitvi volilnih enot za volitve poslancev v Državni zbor leta 2004 odpravljena.

Slika 5: Usklajenost meja volilnih okrajev z občinskimi mejami leta 1992

Figure 5: Harmonization of electoral districts boundaries with municipal boundaries in 1992

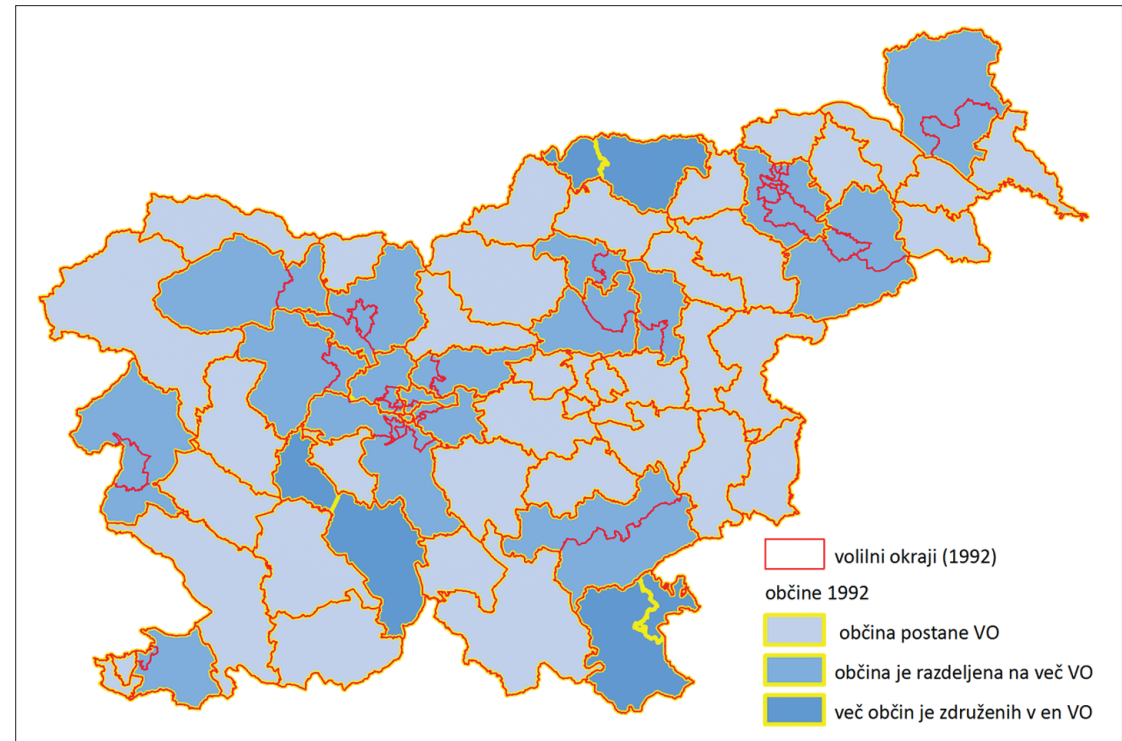

Vir/Source: SURS, 2001 
Zadnja skupina so neskladja, ki so nastala ali zaradi nastanka nove občine na ozemlju dveh starih občin ali zaradi premika posameznih naselij iz ene občine v drugo. Največja tako nastala neskladja je leta 2004 odpravila sprememba Zakona o določitvi volilnih enot za volitve poslancev v Državni zbor. Z njo so bile usklajene občinske in okrajne meje na območju mestnih občin Koper in Celje ter občin Dobrepolje, Loški Potok, Škocjan, Sveti Jurij in Starše (ZDVEDZ-A, 2004). Čeprav je sprememba zakona odpravila vsa največja neskladja, so nekatera še vedno ostala. Tako manjši deli občin Ivančna Gorica, Šentrupert, Zreče in Bohinj ne spadajo v isti volilni okraj kot preostali deli občine. Glavni razlog, da niso bila odpravljena tudi ta neskladja, lahko iščemo $\mathrm{v}$ tem, da spremembe niso bile rezultat sistematičnega dela, temveč so nastale na zahtevo različnih civilnih pobud.

$\mathrm{Na}$ podlagi opisanega lahko trdimo, da reforme lokalne samouprave niso bistveno vplivale na stopnjo usklajenosti občinskih in okrajnih meja, $\mathrm{s}$ tem pa tudi na homogenost in kompaktnost volilnih okrajev. Kljub omenjeni ugotovitvi pa velja poudariti, da so spremembe lokalne samouprave povzročile nekatera nova neskladja, katerih odprava ne bi zahtevala bistvenih posegov v obstoječo ureditev.

Slika 6: Usklajenost meja volilnih okrajev in volilnih enot po letu 2004

Figure 6: Harmonization of electoral districts boundaries with municipal boundaries in 2004

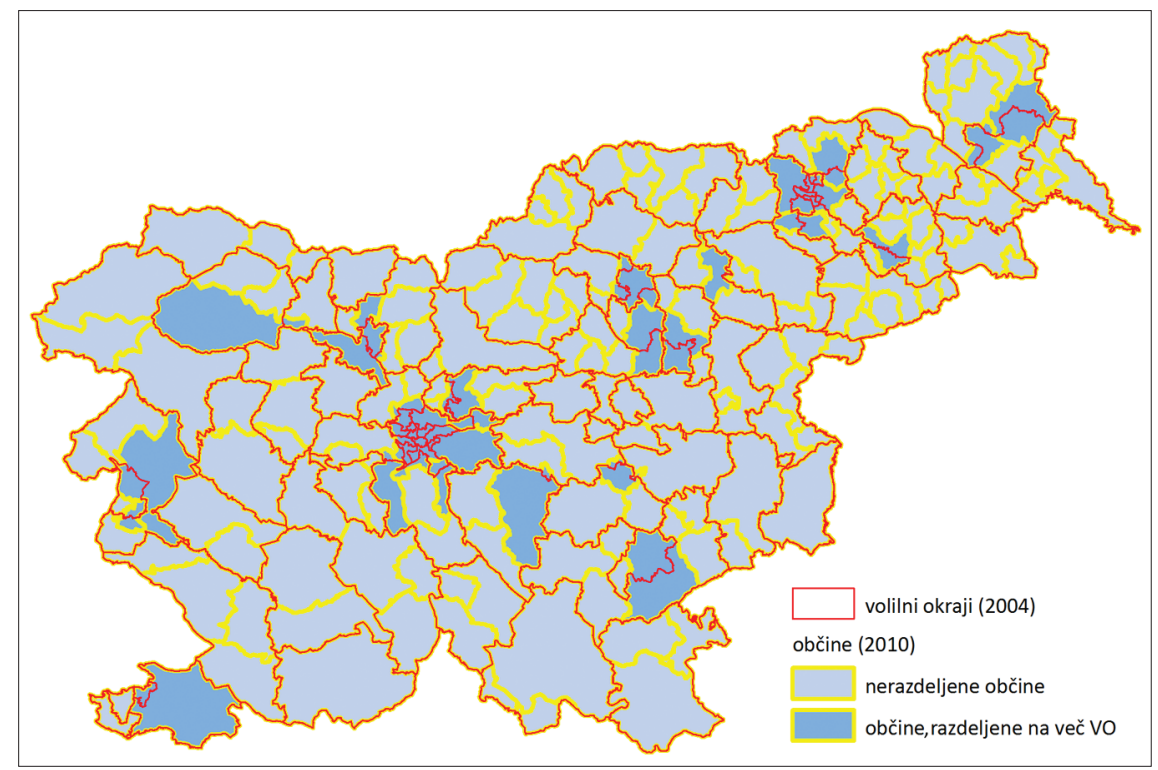

Vir/Source: SURS, 2001

\section{SKLEP}

Pristop, ki je bil uporabljen za oblikovanje volilnih enot v volilnem sistemu za volitve poslancev v Državni zbor Republike Slovenije, je dokaj netipičen za volilne sisteme, zasno- 
vane po proporcionalni formuli. Ker ni bilo primerne upravno-teritorialne členitve države, je bila država razdeljena na osem enajstmandatnih volilnih enot, vsaka volilna enota pa je razdeljena na enajst volilnih okrajev, v katerih poteka kandidiranje in glasovanje. Takšna ureditev zagotavlja visoko stopnjo proporcionalnosti delitve mandatov, geografsko reprezentativnost volilnega sistema, volivcem pa omogoča, da vplivajo na kadrovsko sestavo Državnega zbora. Za opisani pristop načeloma velja, da daje oblikovalcem relativno proste roke pri določitvi prostorskega obsega volilnih enot. Edina večja omejitev je spoštovanje pravičnosti in enakosti, zato je zaželeno, da se pri določitvi prostorskega obsega spoštuje načelo enake volilne pravice, geografske homogenosti in geografske kompaktnosti.

Analiza je pokazala, da obstajajo občutne razlike v stopnji spoštovanja omenjenih načel med volilnimi enotami in volilnimi okraji. Za ureditev volilnih enot sta vse od nastanka naprej značilna visoka stopnja spoštovanja načela enake volilne pravice ter grobo kršenje načel homogenosti in kompaktnosti. Zanimivo je, da ureditev volilnih enot vse od nastanka volilnega sistema leta 1992 ni doživela nobene spremembe, pa je še vedno v celoti skladna z načelom enake volilne pravice. Nasprotno velja za spoštovanje načel homogenosti in kompaktnosti. Omenjeni načeli nista imeli večjega vpliva na določitev prostorskega obsega volilnih enot, zato so te $\mathrm{v}$ večini primerov nehomogene, nekatere pa tudi nekompaktne.

Nasprotno velja za ureditev volilnih okrajev. Členitev države na volilne okraje v osnovi sledi členitvi države na občine leta 1992. Posledično so za ureditev volilnih okrajev vse od nastanka naprej značilne velike razlike v velikosti posameznih okrajev, hkrati pa dokaj visoka stopnja homogenosti in kompaktnosti večine okrajev. Analiza je pokazala, da sodobni demografski trendi niso bistveno vplivali na razlike v velikosti, da pa so številne reforme lokalne samouprave pripomogle $\mathrm{k}$ manjši homogenosti in kompaktnosti nekaterih volilnih okrajev. Čeprav je ureditev volilnih okrajev leta 2004 doživela manjšo revizijo, to ni bistveno vplivalo na njihovo velikost in prostorski obseg. Zaradi nesistematičnega pristopa revizija ni odpravila vseh novih neskladij med mejami občin in volilnih okrajev.

$\mathrm{Na}$ koncu velja rezultate analize povezati z razpravami o reformi obstoječega volilnega sistema. Ureditev volilnih enot in volilnih okrajev v nasprotju z nekaterimi drugimi elementi volilnega sistema vse od leta 1992 ni doživela večjih sprememb (manjše spremembe v prostorskem obsegu nekaterih volilnih okrajev leta 2004 niso bistveno posegle v njuno ureditev). Na relativno stabilnost ureditve so vplivali različni dejavniki. Na prvem mestu velja omeniti dejstvo, da je ureditev obeh še vedno skladna z načeli, na katerih je bila zasnovana. Kot je pokazala analiza, volilne enote še vedno v celoti ustrezajo načelu enake volilne pravice, volilni okraji pa so še vedno geografsko zaokrožena območja s skupnimi kulturnimi in drugimi značilnostmi. Spremembe v razporeditvi prebivalstva in reforma lokalne samouprave niso bistveno vplivale na spoštovanje omenjenih načel. K stanovitnosti ureditve so pomembno pripomogle tudi nekatere odločitve Ustavnega sodišča, ki je večkrat presodilo, da je ureditev volilnih enot in volilnih okrajev skladna z ustavo (Ustavno sodišče, 1992; 2003). Poleg tega v obstoječi zakonodaji ni zakonskega določila, ki bi predvidevalo revizijo velikosti in prostorskega obsega volilnih enot in volilnih okrajev. Opozoriti velja tudi na pomanjkanje politične volje za kakršnekoli spremembe obstoječega sistema. Dosedanje izkušnje kažejo, da je večina političnih akterjev relativno zadovoljna z obstoječo ureditvijo, oziroma da so pogledi na morebitne reforme zelo različni. To je tudi glavni razlog, zakaj 
ureditev personifikacije z glasovanjem po volilnih okrajih, ki velja za enega najspornejših in največkrat kritiziranih elementov obstoječega volilnega sistema, še vedno ni doživela ustrezne revizije (Rogelj, 2011).

Opravljena analiza je pokazala, da ni formalnopravnih razlogov za kakršnokoli reformo ureditve volilnih enot in volilnih okrajev. Na drugi strani se je izkazalo, da nova ureditev lokalne samouprave ustvarja razmere za oblikovanje bolj homogenih oziroma kompaktnih volilnih enot ob hkratnem spoštovanju načela enake volilne pravice, oziroma da je mogoče oblikovati velikostno bolj usklajene, homogene in kompaktne volilne okraje. Seveda pa se pri tem upravičeno postavlja vprašanje o smiselnosti obstoja volilnih okrajev oziroma nujnosti drugačne ureditve personifikacije.

\section{Viri in literatura}

ACE Project, 2011. ACE Project Encyclopedia. URL: http://aceproject.org/ace-en (Citirano 30. 1. 2011).

Cox, G. W., 1997. Making votes count: Strategic coordination in the world's electoral systems. Cambridge, Cambridge University Press, 340 str.

Cox, G. W., Katz, J. N., 2002. Elbridge Gerry’s Salamander: The electoral consequences of the reapportionment revolution. Cambridge, Cambridge University Press, 234 str.

Farrell, D. M., 2001. Electoral systems - A comparative introduction. New York, Palgrave, 241 str.

Gallagher, M., Mitchell, P. (ur.), 2008. The politics of electoral systems. Oxford, Oxford University Press, 662 str.

Grad, F., 2004. Volitve in volilni sistem. Ljubljana, Uradni list RS, 188 str.

Grad, F., 2011. Oblikovanje državnozborskega volilnega sistema (osebni vir, 25. 6. 2011). Ljubljana.

Gudgin, G., Taylor, P. J., 1979. Seats, votes and the spatial organization of elections. London, Pion, 240 str.

Harrop, M., Miller, W. L., 1987. Elections and voters: A comparative introduction. London, Macmillan, 297 str.

Klemenčič, M. M., 2005. Regija in regionalna struktura Slovenije. Dela, 23, str. 5-58.

Krašovec, A., 2007. Volilne študije. Ljubljana, Fakulteta za družbene vede, 204 str.

Kropivnik, S., 1993. Proučevanje volilnih izidov. Teorija in praksa, 30, 9/10, str. 937-949.

Kropivnik, S., 1996. Volilna geografija ter družbeni in ideološki profili sodobnih slovenskih političnih strank. Doktorsko delo. Ljubljana, Fakulteta za družbene vede, 300 str.

Latner, M., McGann, A. J., 2004. Geographical representation under proportional representation: The cases of Israel and the Netherlands. Center for the Study of Democracy, UC Irvine. URL: http://escholarship.org/uc/item/1q34f69c (Citirano 20. 6. 2011).

Lijphart, A., 1994. Electoral systems and party systems - a study of twenty-seven democracies, 1945-1990. Oxford, Oxford University Press, 209 str.

Monmonier, M., 2001. Bushmanders and bullwinkles: How politicians manipulate electronic maps and census data to win elections. Chicago, The University of Chicago Press, 208 str. 
Monroe, B. L., 1994. Disproportionality and malapportionment: Measuring electoral inequity. Electoral studies, 13, 2, str. 132-149.

Monroe, B. L., Rose, A. G., 2002. Electoral systems and unimagined consequences: partisan effects of districted proportional representation. American journal of political science, 46, 1, str. 67-89. URL: http://www.jstor.org/stable/3088415 (Citirano 20. 6. 2012).

Morrill, R. L., 1981. Political redistricting and geographic theory. Washington, Association of American Geographers, 76 str.

Norris, P., 2004. Electoral engineering: voting rules and political behavior. Cambridge, Cambridge University Press, 375 str.

Plut, D., 2004. Načela, kriteriji in regionalizacija Slovenije z vidika členitve na pokrajine. V: Vlaj, S. (ur.). Pokrajina: druga raven lokalne samouprave. Ljubljana, Inštitut za lokalno samoupravo pri Fakulteti za upravo, str. 21-35.

Predčasne volitve v Državni zbor 2011, 4. december 2011. Državna volilna komisija (DVK). URL: http://volitve.gov.si/dz2011/ (Citirano 25. 2. 2011).

Rae, D. W., 1971. The political consequences of electoral laws (2nd edition). New Haven, London, Yale University Press, 203 str.

Reynolds, A., Reilly, B., 1997. The international IDEA handbook of electoral system design (2nd edition). Stockholm, International IDEA, 167 str.

Rogelj, B., 2011. Političnogeografska analiza volilnega sistema volitev v Državni zbor Republike Slovenije. Doktorsko delo. Ljubljana, Filozofska fakulteta, Oddelek za geografijo, 172 str.

SURS, 1996. Volilna statistika in referendumi: Volitve v Državni zbor, Republika Slovenija, 10.11. 1996. Statistični urad Republike Slovenije. Statistične informacije, 332, str. 1-14.

SURS, 2000. Državnozborske volitve 2000, Slovenija. Statistični urad Republike Slovenije. Rezultati raziskovanj, 750, 95 str.

SURS, 2001. Katalog regionalnih delitev Slovenije 2001. Statistični urad Republike Slovenije. URL: http://www.stat.si/KatalogRDS/start.html (Citirano 20. 6. 2012).

SURS, 2004. Državnozborske volitve, Slovenija, 3. 10. 2004. Statistični urad Republike Slovenije, Rezultati raziskovanj, 818, 95 str. URL: http://www.stat.si/doc/pub/rr-81805.pdf (Citirano 20. 6. 2012).

SURS, 2011. SI-Stat podatkovni portal. Statistični urad Republike Slovenije. URL: http:// pxweb.stat.si/pxweb/Database/Dem_soc/Dem_soc.asp\#05 (Citirano 2. 4. 2011).

Taylor, P. J., Johnston, R. J. 1979. Geography of elections. London, Croom Helm, 528 str.

Toplak, J., 2000. Volilni sistem in oblikovanje volilnih enot. Ljubljana, Nova revija, 140 str.

Ustavno sodišče, 1992. Odločba U-I-128/92. URL: http://odlocitve.us-rs.si/usrs/us-odl.nsf/ o/4E3CBE00CEA0E9BFC125717200280BA8 (Citirano 10. 3. 2010).

Ustavno sodišče, 2003. Odločba U-I-226/00. URL: http:/odlocitve.us-rs.si/usrs/us-odl.nsf/ o/EEFBA893FCCA3E43C125717200288C33 (Citirano 2. 4. 2011).

Volitve v Državni zbor 2008, 21. september 2008. Državna volilna komisija (DVK). URL: http://volitve.gov.si/dz2008/ (Citirano 15. 9. 2009).

Zakon o spremembah in dopolnitvah Zakona o določitvi volilnih enot za volitve poslancev v Državni zbor, 2004 (ZDVEDZ-A). Uradni list RS, 80/2004 (23. 7. 2004). URL: http:// www.uradni-list.si/1/index?edition=200480 (Citirano 2. 4. 2011). 


\title{
ARRANGEMENT OF CONSTITUENCIES IN ELECTORAL SYSTEM USED FOR THE ELECTIONS TO THE NATIONAL ASSEMBLY OF SLOVENIA
}

\begin{abstract}
Summary
In electoral systems that are based on proportional electoral formulas, the division of territory into constituencies is not fundamentally required and sometimes not even desired. Each division of territory into constituencies reduces the degree of proportionality for the distribution of mandates, which is why it is used in such systems only when the electoral system must fulfil another aim besides that of proportionality (Rogelj, 2011). A great variety in constituency's designs is characteristic of such systems, since there are no rules that have to be followed in the design process. The only limit that must be respected is linked to ensure fairness and equality. This is seen in the degree of respect for the principle of voter equality, geographic homogeneity and geographical compactness of constituencies. In accordance with the first principle, an electoral system must be created to ensure that every vote is of equal value (Grad, 2004) or, that an equal number of residents/voters determines one mandate. The principle of homogeneity concerns the demand that the borders of a constituency do not divide social groups that live in a spatially delineated area (ACE Project, 2011). The principle of compactness pertains to the need for constituencies to be close and compact spatial units.

There are two approaches in designing constituencies in electoral systems based on proportional representation (Rogelj, 2011). The first group are electoral systems pre-determined by the spatial extent of a constituency, where the district magnitude is determined according to the number of residents or some other measure. When constituencies are created in that way, the principles of homogeneity and compactness have priority over voter equality.

The second group are the systems with pre-defined district magnitude, followed by the structuring of their spatial extent (Rogelj, 2011). Although this approach is typical of majority-based electoral systems, it is, exceptionally, also found in systems that are based on proportional representation. In such cases, this approach is generally linked with a statutory provision, according to which each constituency elects an equal number of mandates, and without adequate administrative division of the territory in which elections are being held. Here the principles of homogeneity and compactness are subordinated to the principle of voter equality.

The organization of constituencies in the electoral system for representatives into the National Assembly of the Republic of Slovenia belongs to the second group. Because the state was not suitably structured in administrative and territorial terms, it was divided into eight constituencies with eleven mandates each, and each constituency further divided into eleven electoral districts. This organization ensures a high degree of proportionality in the distribution of mandates, geographical representation in the electoral system, and it allows voters to influence the composition of the National Assembly.

An analysis of organization of constituencies and electoral districts in the light of the principles of voter equality, geographical homogeneity and geographical compactness re-
\end{abstract}


veals that significant differences exist in the level of respect for these principles among constituencies and electoral districts. Characteristic for the organization of constituencies, from the start, was a high degree of respect for the principle of voter equality and obvious transgressions against the principles of homogeneity and compactness. Interestingly, the organization of the constituencies has not changed at all since the Slovenian electoral system was created in 1992; it remains, however, fully consistent with the principle of voter equality. The opposite holds true for the observance of the principles of homogeneity and compactness. These principles have not had a significant influence on determining the spatial extent of constituencies, which is why for the most part they are not homogenous, and sometimes they are also not compact.

The opposite holds true for the organization of electoral districts. The structuring of the country into electoral districts is based on the 1992 municipal division. Consequently, from the start, the organization of electoral districts has been marked by great differences in the size of individual districts, though there is a fairly high degree of homogeneity and compactness in most districts. The analysis shows that modern demographic trends did not significantly change the population differences among electoral districts, but that many reforms at the local administrative level have led to a reduction in homogeneity and compactness in certain electoral districts. Although the organization of electoral districts underwent minor revision in 2004, this revision did not significantly affect their size and spatial extent. Because the revision was carried out in an unsystematic manner, it did not eliminate all of the newly-arisen discrepancies between municipal and electoral district borders.

The completed analysis shows that there are no formal legal grounds for any sort of reform to the organization of constituencies and electoral districts in Slovenia. On the other hand, it is evident that the new organization of local administration creates the conditions for the creation of more homogenous or compact electoral districts, while respecting the principle of voter equality, and that it is possible to create much more balanced, homogenous and compact electoral districts. In this regard, it is entirely justified to raise the question of the reasonableness of the existing electoral districts and the need for a personification that is organized in a different manner.

(Translated by dr. Jason Blake) 